\title{
表面取水施設における渦対策工の 空気取り込み渦に及ぼす影響に関する実験的研究 EXPERIMENTAL STUDY ON EFFECTS OF VORTEX-PREVENTING DEVICES FOR SUPPRESSING AIR ENTRAINMENT INSIDE SURFACE INTAKE FACILITY
}

\author{
竹原幸生 1 ・ 久末信幸 2 ・高野保英 3 \\ Kohsei TAKEHARA, Nobuyuki HISASUE and Yasuhide TAKANO \\ 1正会員 博(工) 近畿大学教授 理工学部社会環境工学科（†577-8502 東大阪市小若江3-4-1） \\ 2正会員 博(工) 関西電力株) 電力技術研究所構築研究室（广661-0974 尼崎市若王寺3-11-20） \\ 3正会員 博(工) 近畿大学講師 理工学部社会環境工学科（†577-8502 東大阪市小若江3-4-1）
}

\begin{abstract}
Air entrainments by vortices at water surfaces inside surface intake facilities of electrical power plants cause some problems, such as deterioration of power generation, destruction of blade in a turbine, etc. To suppress air entrainments by the vortices, some vortex-preventing devices have been proposed and have been used in many electrical power plants. The vortex-preventing devices used in the intake facilities are working effectively in many cases. However, the hydraulic properties of flow structure by the vortexpreventing devices are still unclear.

In this paper, the effects of the vortex-preventing devices in surface intake facilities have been investigated experimentally by using the particle tracking velocimetry. The results show that the vortexpreventing devices suppress the turbulent intensity and the vorticity inside the facility.
\end{abstract}

Key Words : hydraulic power plant, surface intake facility, air entrainment, PTV, MLS

\section{1.はじめに}

水力発電施設等における取水施設では，取水口付近に 生じる取水渦が表面から空気を取り込み，発電施設にま で達して問題が生じることはよく知られている.一般に, 圧力水路内に混入した空気は，空気塊を形成し取水口や 水槽の自由水面で解放され，エアハンマーとなって水力 発電施設のコンクリート身区体に悪影響を与える ${ }^{1)}$. また, 水車発電機の羽根車にキャビテーションを生じさせ, さ らには，発電能力の低下を招き，問題となっている ${ }^{2)}$.

空気取込み渦の研究は，古くから行われている ${ }^{3) ~ 5) . ~}$ 例えば，渦により生じる水面形状により空気取り込み渦 の発生規模を評価する手法が考案されている ${ }^{3)}$.また, 実際の水力発電施設の取水口やポンプ取水槽に発生する 空気取り込名渦の研究も行われている ${ }^{5)}$.さらに，取水 施設での空気取り込み防止のための渦対策工が実験的に 検討されてきた.

近年の電子計算機の著しい進歩により, 数值計算で 空気取り込み渦発生を予測する試みがなされている. し かし, 空気取り込み渦の発生を正確に判断するには，水 表面の条件を厳密に再現できる計算スキームの開発が必 要となり, 現在, 精力的に開発が行われている. 例えば, 水面計算を組み込んだ LES（Large-Eddy Simulation）法

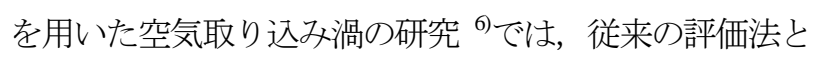
同様に，空気取り込み渦の水面形状から空気取り込み渦 の発生規模の評価を行う試みがなされている.しかし, 現状では数值計算による空気取り込み渦の発生予測を行 うには，検証が必要な状況にある.

瞬時の二次元場の流れ場を計測する手法として PIV (Particle Image Velocimetry) を代表とした画像計測法が 開発されてきた. 画像計測法の利点は点計測に比べて流 れ場の時空間構造を直接計測することが可能となる点で ある. 特に, PIV の中でも個々の粒子を追跡し, 流速を 計測する PTV (Particle Tracking Velocimetry) は, 高分解 能で計測が可能である ${ }^{7}$. しかし, 空気取り込み渦の画 像計測に関する既往研究はほとんどなく, 空気取り込み 渦の時空間的な流れ場構造についても不明な点が多い.

本研究では, 貯水池から水力発電施設一表面取水する 場合に用いられる一般的な取水施設を対象に，ピア部の 曲率や渦防止桁などの渦対策工の流れ場への水理学的効 果をPTVにより明らかにすることを目的としている.

\section{2. 実験装置および実験方法}

\section{（1）実験水路}

実験装置の概要図を図-1 に示す. 水力発電施設の表 面取水設備で用いられるべルマウス形式の取水設備を対 


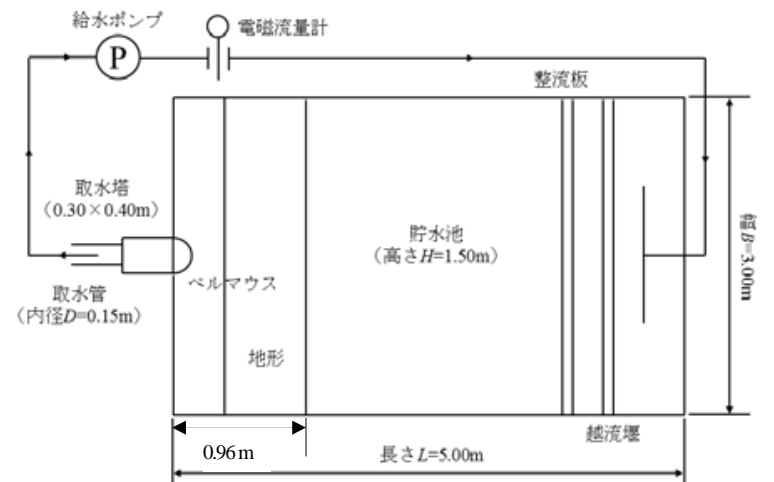

(a) 平面図

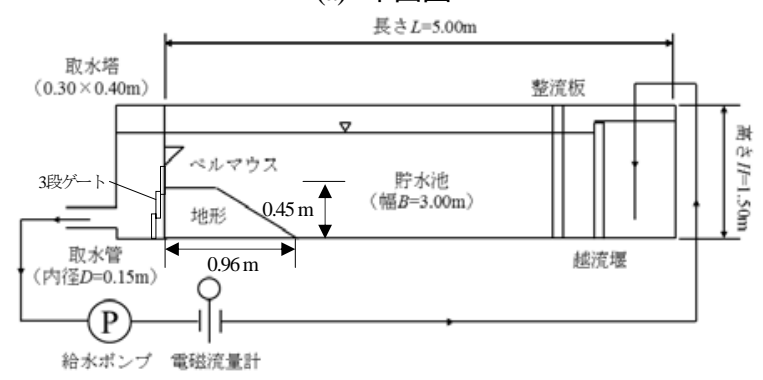

(b) 断面図

図-1 実験装置の概要図

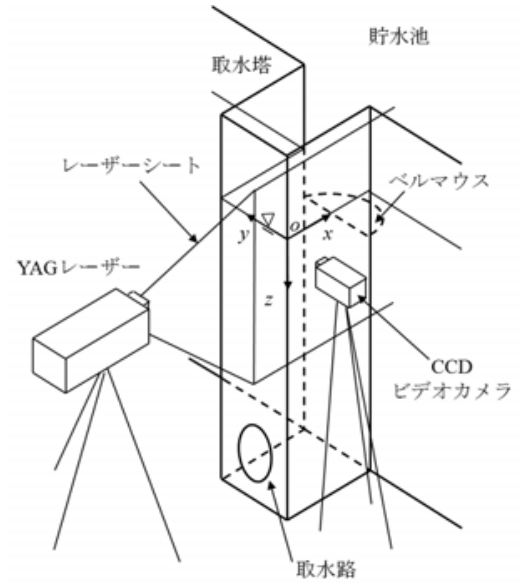

図-2ＰTV計測法の概略図

表-1 実験条件

\begin{tabular}{|c|c|c|c|c|}
\hline \multicolumn{2}{|c|}{ ケース } & Case1 & Case2 & Case3 \\
\hline \multicolumn{2}{|c|}{ ピア形状 } & 曲率なし & \multicolumn{2}{|c|}{ 曲率あり } \\
\hline \multicolumn{2}{|c|}{ 渦防止桁 } & なし & なし & あり \\
\hline \multicolumn{2}{|c|}{ 流量 $Q\left(\mathrm{~m}^{3} / \mathrm{sec}\right)$} & \multicolumn{3}{|c|}{0.012} \\
\hline \multicolumn{2}{|c|}{ 水位 $\mathrm{z}(\mathrm{m})$} & \multicolumn{3}{|c|}{1.230} \\
\hline \multirow{2}{*}{ 計測位置 } & 水平断面 & \multicolumn{3}{|c|}{$\mathrm{z}=0.04(\mathrm{~m})$} \\
\hline & 鉛直断面 & \multicolumn{3}{|c|}{$\mathrm{y}=0.128(\mathrm{~m})$} \\
\hline
\end{tabular}

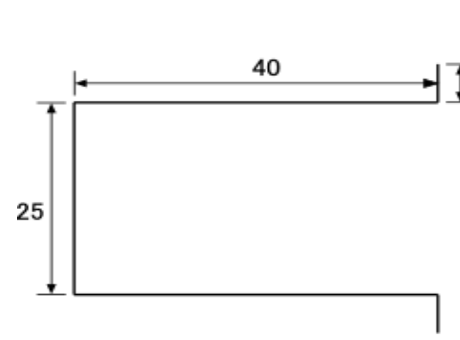

(case1)

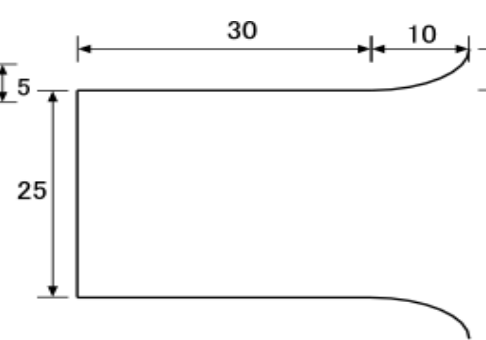

(case2)

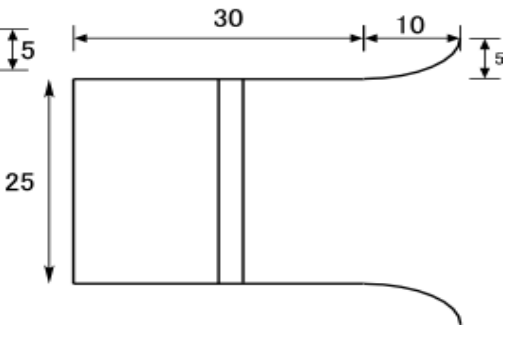

(case3)

(unit: $\mathrm{cm}$ )

図-3 取水施設の形状

象とし, 貯水池からベルマウス, 取水施設, 取水路まで の模型（長さ $L=5.000 \mathrm{~m}$, 幅 $B=3.000 \mathrm{~m}$, 高さ $H=1.500 \mathrm{~m}$, 取水路内径 $\phi=0.150 \mathrm{~m}$ ）を用いた. 循環式の水路とし, 所定の流量 $\left(Q=0.012 \mathrm{~m}^{3} / \mathrm{s}\right)$ を電磁流量計で制御し, 貯 水池の水位を一定に保つようにした.

貯水池は模型にかかる水圧を考慮して鋼製の水槽とし た. 取水施設は通常河岸に設置されるため前面の地形は 斜面になっており，その地形は木製の部材で製作した. レーザー光を照明とする PTV 計測を行うため, 取水施 設を透明のアクリル材で製作した，また，表層取水のた めベルマウスの高さ調節は３段ゲートを用いた。

PTV 計測装置の概要図を図-2 に示す。今回使用した 計測装置は, 取水施設内の水面近傍の水平断面内および 取水施設中央の鉛直断面内の流れ場を計測する. 座標原 点 $O$ を終端壁と左岸の交点の水面位置とし, $x$ 軸は上流 方向を正， $y$ 軸は右岸方向を正， $z$ 軸は鉛直下向きを正 とした. また， $x$ 軸， $y$ 軸， $z$ 軸方向の流速をそれぞれ $u$, $v, w$ とする.

\section{（2）PTV 計測装置}

PTV 計測装置は，YAG ダブルパルスレーザー (120mJ/pulse) , CCD ビデオカメラ（1600×1200pixel）, 制御用 PC から構成される. 照明光であるレーザービー ムは，シリンドリカルレンズによりシート状に変換され， 計測断面に照射された. 今回使用した PTV 計測装置で は，ダブルパルスレーザーの各パルス間隔を $10 \mathrm{msec}$, 連続する 2 枚の画像の組は $10 \mathrm{~Hz}$ 間隔とした. 694 組の 2 枚の画像を取得し，計測時間は69.4secであった。

トレーサー粒子としてナイロン 12 粒子（平均粒径

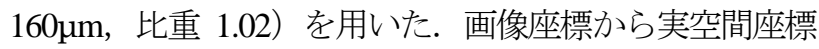
への変換は，レンズ歪等に対応できるよう 2 次関数変換 を用いた. 変換係数は，5cm 間隔の標定点 65 個の標定 板を用い最小自乗法により求めた. PTV アルゴリズム は，竹原ら ${ }^{7)}$ の Super-resolution KC 法を用いた。 


\section{（3）データの処理法}

PTV により得られる流速值は, トレーサー粒子が存 在する点で定義される，得られた結果は，任意の点にお ける流速ベクトル分布となる. 乱流統計量の空間分布や 変化を比較的求め易く寸るために, 任意の点の流速べク トル分布を格子点の流速ベクトル分布に变換した. 格子 点への変換は，ガウス分布の重み付き平均を用いた. 重 み関数であるガウス分布関数の偏差值には, PTV 計測 により求められた粒子数から求められる平均的な粒子間 隔の 2 倍を用いた. 変換された格子点の流速ベクトル分 布を用いて平均流速ベクトル分布を算出した.

渦度分布については, ランダムな点における流速べ クトル分布を用いて, 直接渦度を求める MLS 法

(Moving Least Square） ${ }^{8)}$ にって算出した.

\section{（4）実験条件}

実験条件を表-1 に，渦対策工として用いたピア部の 曲率および渦防止桁の概要図を図-3 に示す．ピア部の 曲率および渦防止桁の有無の変化による取水施設内の流 況の違いを比較するために 3 ケースの実験を行った. 通 常取水施設における取水流速は $1 \mathrm{~m} / \mathrm{sec}$ 以下に抑えられ るため, 渦防止桁による水面変動や抵抗増加等の影響は 小さいものと考えられる.

取水施設での水深は $1.230 \mathrm{~m}$ に固定して実験を行った. PTV 計測位置は, 水平断面と鉛直断面の 2 断面とした. 水平断面は渦流れが顕著に見られる水面近傍を計測する ため $z=0.04 \mathrm{~m}$ の水平断面とした. また, 鉛直断面は代 表断面として取水施設中央 $(y=0.128 \mathrm{~m})$ とした. 照明光と するレーザー光は, 取水施設下流終端壁のアクリル面を 通して下流側から上流側に向け照射した. 画像の撮影方 向は取水施設左岸側の下方から撮影した.

本実験条件における各ケースの空気取り込み渦の発 生規模は, 既往の評価方法 9り基づき目視により観察し た. case1 および case2 は渦大に分類され，ピア曲率の ある case2 は, case1 と比べ渦の発生頻度は少なかった. また, case3 は水面の窪みはほとんど見られなかった。

\section{3．流速に関する統計量}

\section{（1）平均流速分布}

各ケースの平均流速ベクトル分布を図-4 に示す. 取 水施設内の水面近傍の水平断面は, 図の右側が取水施 設流入部，左側が取水施設下流終端壁で，流れは図の 右側から左側に向かって流れている. 取水施設中央の 鉛直断面は, 図の右側が取水施設流入部でベルマウス 部の終端, 左側が取水施設下流終端壁となっている. 流れは図の右側から左側に向かって流れ, その後, 取 水施設内で下側に流れている. 図中の左下の実線部分 は，3段ある取水午ートのうちの最上段にある取水ゲー 卜の設置位置を示している.

case1 の平均流速ベクトル分布を図-4 (a) に示寸. 水 平断面では，ピアから剥離した流れが取水施設中央に 集中し，左右にそれぞれ分かれ時計回り，反時計回り
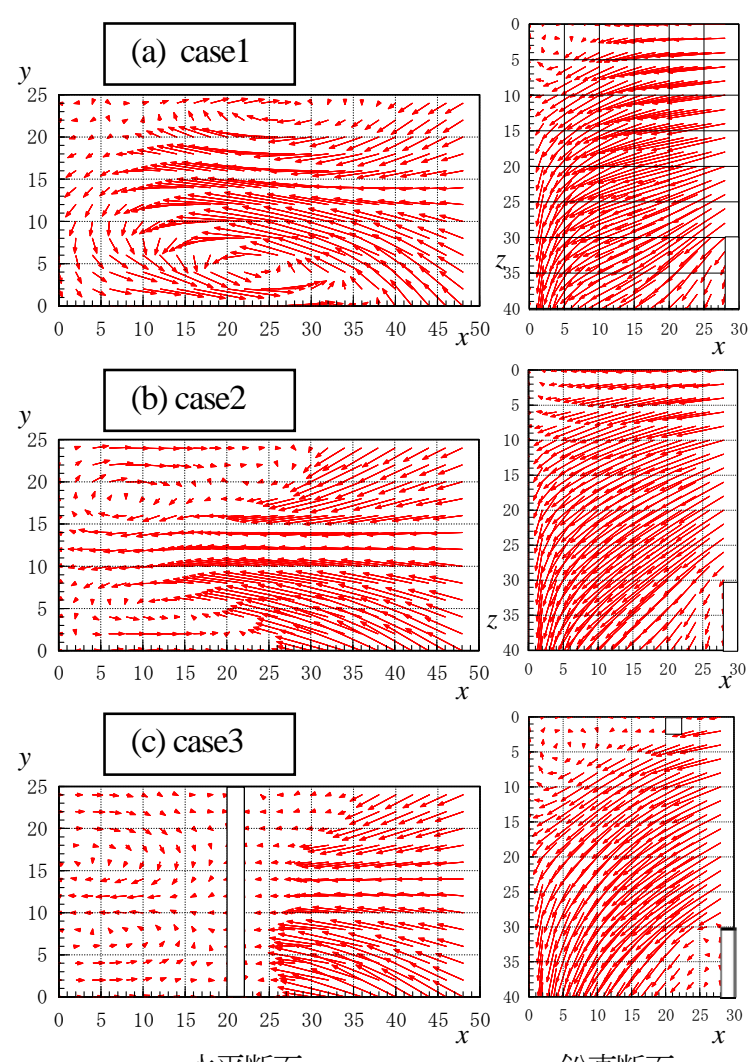

図-4 平均流速分布 （座標単位: $\mathrm{cm}$ )

の旋回流が形成されている. 左岸側の反時計回りの平 均的な旋回流が卓越しており, 平均的な旋回流の中心 位置は $(x, y)=(23.5 \mathrm{~cm}, 5 \mathrm{~cm})$ であった. case1 の鉛直断面で は, 取水施設下流終端壁の水面近傍には時計回りの小 さな旋回流が見られる. ベルマウスから取水施設の接 合部(図中の白い $\square$ )から流れ込む流れが剥離しているの がわかる. 図の左下に取水管があり, 取水施設流入部 から流入した流れが取水路に向かって流れている.

case2 の平均流速ベクトル分布を図-4 (b) に示寸. case2 は case1 のピア部に曲率を付けたものある. 水平 断面の流速分布より, ピア部の曲率のために $x=30 \mathrm{~cm}$ 付 近から取水施設に流入しているのがわかる. case1 と同 様に左岸側の反時計回りの旋回流が卓越しているが, 旋回の中心位置は $(x, y)=(13 \mathrm{~cm}, 6 \mathrm{~cm})$ と終端壁方向に移動 している. case2 の鉛直断面の流れ場は case1 の場合と ほぼ同样に終端壁水面近傍の小さな旋回流とベルマウ ス接合部での剥離が確認できる.

case3 の平均流速ベクトル分布を図-4 (c) に示寸. case3 は case2 にさらに $x=20 \mathrm{~cm}$ の水面近傍に渦防止桁 を設置している. 水平断面では, 渦防止桁の上流側お よび下流側には旋回流はほとんど見られない，鉛直断 面では, 渦防止桁設置位置から下流の水面近傍に逆三 角形の死水領域が明確に形成されており, ベルマウス 接合部での剥離領域がより明確に形成されている.

\section{（2）乱れ強度分布}


(case1)
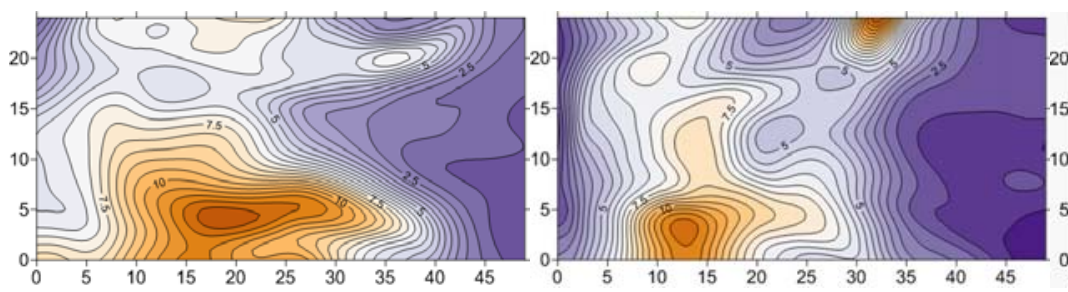

(a) 乱れ強度 $\sqrt{\overline{u^{\prime 2}}}$ 分布
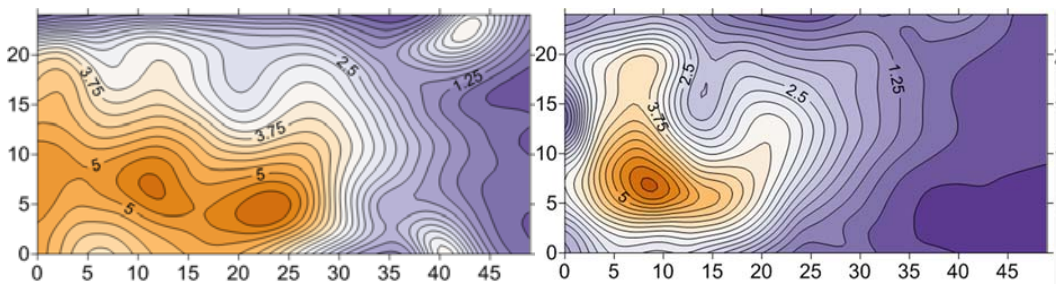

(b) 乱れ強度 $\sqrt{v^{\prime 2}}$ 分布

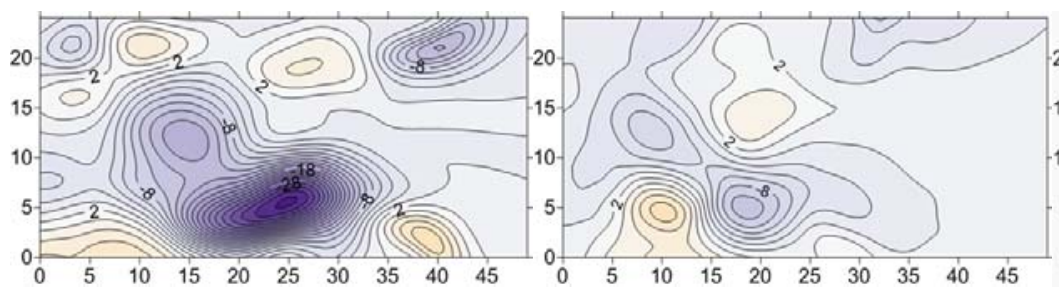

(c) レイノルズ応力 $-\overline{u^{\prime} v^{\prime}}$ 分布

図-5 水平断面 $(z=0.04 \mathrm{~m})$ の乱れ強度分布（横軸 $x$ 軸，縦軸 $y$ 軸， 単位 $\mathrm{cm}$ )

\section{(a) 乱れ強度およびレイノルズ応力の水平断面分布}

取水施設内の水平断面の乱れ強度 $\left(\sqrt{u^{\prime 2}}, \sqrt{v^{\prime 2}}\right)$ 分布お よびレイノルズ応力 $\left(-\overline{u^{\prime} v^{\prime}}\right)$ 分布を図-5に示す.

まず，図-5(a)に水平断面の $x$ 軸方向の乱れ強度 $\sqrt{{u^{\prime 2}}^{2}}$ 分布を示している．ピア曲率がなく渦防止桁がない case1 の場合には, 左岸側に乱れ強度 $\sqrt{u^{\prime 2}}$ の大きな領域 がある. 対称の実験装置でも取水渦のような不安定現 象ではどちらか一方の渦が卓越する傾向があり, 本実 験では左岸側の取水渦のスケール, 強度が卓越した。 この現象は case2 の場合も同様の結果となった.

case1 の乱れ強度 $\sqrt{u^{\prime 2}}$ のピーク位置は $(x, y)=(18.0 \mathrm{~cm}, 4.0$ $\mathrm{cm})$ で，ピーク值は $12.42 \mathrm{~cm} / \mathrm{sec}$ であった. case2 の場 合は case1 の場合と同様に左岸側に乱れ強度が大きい領 域があるが，その領域は小さくなっている. case2 の場 合のピーク位置 $(x, y)=(13.0 \mathrm{~cm}, 3.0 \mathrm{~cm})$ でピーク值は 11.79 $\mathrm{cm} / \mathrm{sec}$ であった. さらに渦防止桁を設置した case3 の 場合には左岸側に生じていた乱れ強度の大きな領域は 消失している.

次に，図-5(b) に水平断面の $y$ 軸方向の乱れ強度 $\sqrt{v^{12}}$ 分布を示している. case1 の場合は $x$ 軸方向の乱れ強度 $\sqrt{u^{\prime 2}}$ 分布と同様に左岸側に乱れ強度 $\sqrt{v^{\prime 2}}$ の大きな值の領 域が生じており，特徵的には 2 つのピークが現れてい る. 2 つのピークはそれぞれ位置 $(x, y)=(23.0 \mathrm{~cm}, 4.0 \mathrm{~cm})$ と $(x, y)=(11.0 \mathrm{~cm}, 7.0 \mathrm{~cm})$ で，ピーク值は $5.73 \mathrm{~cm} / \mathrm{sec}$ と 5.56 $\mathrm{cm} / \mathrm{sec}$ であった．ピア曲率がある case2 の場合, 乱れ強 度 $\sqrt{v^{2}}$ の大きな領域は小さくなり，ピーク位置は終端壁 方向に移動している. case2 の場合のピーク位置は $(x, y)$
$=(9 \mathrm{~cm}, 5 \mathrm{~cm})$ でピーク值は $7.39 \mathrm{~cm} / \mathrm{sec}$ であった. case 3 の場合は洞防止林の効果により, 乱れ強度 $\sqrt{v^{\prime 2}}$ の大きな 領域は消失している.

図-5(c)にレイノルズ応力- $\overline{u^{\prime} v^{\prime}}$ の分布を示す. ピア曲 率のない case1 では, 左岸側近傍に負の大きなレイノル ズ応力(ピーク值 $\left.-36.23 \mathrm{~cm}^{2} / \mathrm{sec}^{2}\right)$ が見られる. しかし，ピ ア曲率がある case2 では, レイノルズ応力が低く抑えら れている(ピーク值-10.94 $\left.\mathrm{cm}^{2} / \mathrm{sec}^{2}\right)$. さらに渦防止栴を設 置によりレイノルズ応力の大きな領域は消失いている.

\section{(b) 乱れ強度およびレイノルズ応力の鉛直断面分布}

取水施設内の鉛直断面の乱れ強度 $\left(\sqrt{u^{\prime 2}}, \sqrt{w^{\prime 2}}\right)$ および レイノルズ応力 $\left(-\overline{u^{\prime} w^{\prime}}\right)$ 分布を図-6に示す.

まず，図-6(a)に示寸乱れ強度 $\sqrt{u^{\prime 2}}$ の分布に関しては, ピア曲率がない case1 とピア曲率がある case2 で，双方 に終端壁水面近傍に乱れ強度が大きい領域が見られる. case1 の場合のピーク位置は $(x, z)=(12.0 \mathrm{~cm}, 3.0 \mathrm{~cm})$ でピー ク值は $8.90 \mathrm{~cm} / \mathrm{sec}$ であり, case2 の場合のピーク位置は $(x, z)=(9.0 \mathrm{~cm}, 5.0 \mathrm{~cm})$ でピーク值は $7.39 \mathrm{~cm} / \mathrm{sec}$ であった. 渦方止桁を設置した case3 の場合, 終端壁水面近傍の乱 れ強度は低く抑えられている。

次に, 図-6(b)に示寸乱れ強度 $\sqrt{w^{12}}$ に関しては, ベル マウス接合部より生じる剥離域に沿った大きな領域が ある. ピア曲率がない case1 の場合はピーク位置は $(x, z)$ $=(21 \mathrm{~cm}, 37 \mathrm{~cm})$ で, ピーク值は $7.23 \mathrm{~cm} / \mathrm{sec}$ であった. 曲 率がある case2 の場合のピーク位置は $(x, Z)=(22 \mathrm{~cm}, 32 \mathrm{~cm})$ でピーク值は $6.38 \mathrm{~cm} / \mathrm{sec}$ と case 1 に比べて小さな值と なった．渦方止桁を設置した case3 の場合，主流部の乱 

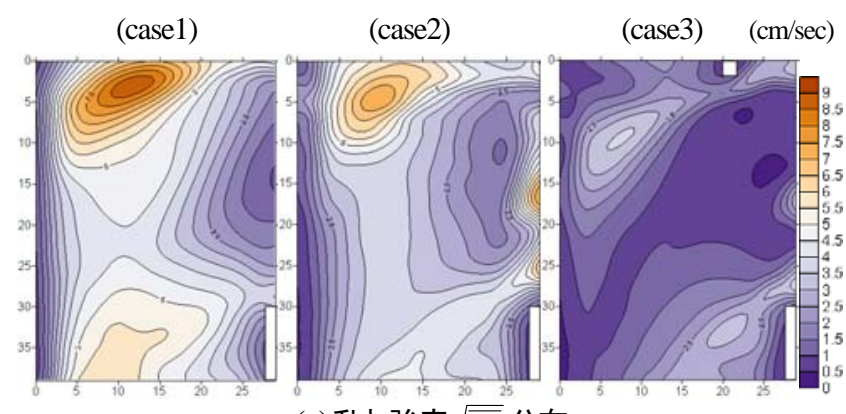

(a)乱れ強度 $\sqrt{\overline{u^{\prime 2}}}$ 分布
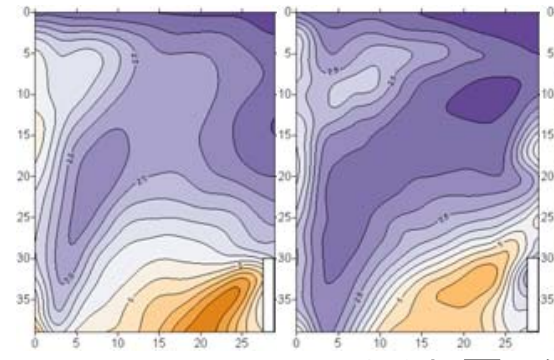

(b) 乱れ強度 $\sqrt{w^{\prime 2}}$ 分布

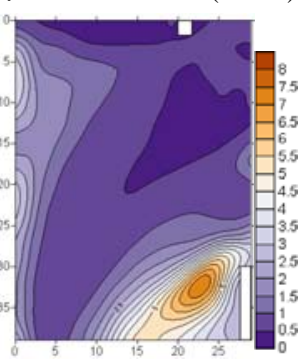

$\left(\mathrm{cm}^{2} / \mathrm{sec}^{2}\right)$

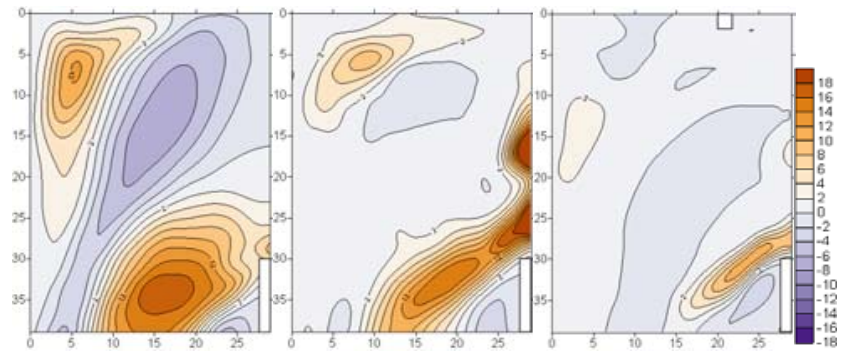

(c) レイノルズ応カ $-\overline{u^{\prime} w^{\prime}}$ 分布

図-6 鉛直断面 $(y=0.128 m)$ の乱れ強度速分布

（横軸 $x$ 軸，縦軸z軸，単位 $\mathrm{cm}$ )

れが大きく抑制されている。ベルマウス接合部からの 剥離域に沿った乱れ強度 $\sqrt{\text { w }^{\prime 2}}$ は他のケースと同様で, ピーク位置は $(x, z)=(23.0 \mathrm{~cm}, 32 \mathrm{~cm})$ でピーク值は $7.44 \mathrm{~cm}$ /secであった.

図-6(c)にレイノルズ応力- $\overline{u^{\prime} w^{\prime}}$ 分布を示している. ピ ア曲率がない case1 では, 終端壁の水表面付近に逆三角 形のレイノルズ応力が正の領域があり(ピーク位置 $(x, z)=(5 \mathrm{~cm}, 7 \mathrm{~cm})$, ピーク值 $\left.12.18 \mathrm{~cm}^{2} / \mathrm{sec}^{2}\right)$, その斜め下 方に楔形の負の領域(ピーク位置 $(x, z)=(15 \mathrm{~cm}, 14 \mathrm{~cm})$, ピーク值- $\left.7.76 \mathrm{~cm}^{2} / \mathrm{sec}^{2}\right)$ が見られる. また, 取水路付近の 剥離域に沿った領域にレイノルズ応力の大きな正の領 域(ピーク位置 $(x, z)=(15 \mathrm{~cm}, 34 \mathrm{~cm})$, ピーク值 $17.71 \mathrm{~cm}^{2}$ $\left./ \mathrm{sec}^{2}\right)$ が見られる。ピア曲率がある case2 では, case1 に 比べて終端壁の水表面付近に逆三角形の正の領域(ピー ク位置 $(x, z)=(9 \mathrm{~cm}, 6 \mathrm{~cm})$, ピーク值 $\left.9.21 \mathrm{~cm}^{2} / \mathrm{sec}^{2}\right) や$, そ の斜め下方に楔形の負の領域 (ピーク位置 $(x, z)=(15 \mathrm{~cm}$, $8 \mathrm{~cm})$, ピーク值 $\left.-1.93 \mathrm{~cm}^{2} / \mathrm{sec}^{2}\right)$ のレイノズ応力が小さ く抑えられている. また, ベルマウス接合部からの剥 離領域に沿った正の領域(ピーク位置 $(x, z)=(18 \mathrm{~cm}, 33 \mathrm{~cm})$, ピーク值 $\left.15.84 \mathrm{~cm}^{2} / \mathrm{sec}^{2}\right)$ が細長くなっているのがわかる.

また，渦防止桁がある case3 では，終端壁の水表面付 近の逆三角形の正の領域や, その斜め下方の楔形の負
の領域がほとんど消失している. 取水路付近の剥離領 域に沿った領域(ピーク位置 $(x, z)=(25 \mathrm{~cm}, 29 \mathrm{~cm})$, ピーク 值 $\left.11.78 \mathrm{~cm}^{2} / \mathrm{sec}^{2}\right)$ は小さく, レイノルズ応力が低く抑え られているのがわかる。 また，渦防止桁により取水口 に向から流れが整流されているため, 渦防止析付近の レイノルズ応力は低く抑えられている.

\section{4. 渦度に関する統計量}

\section{（1） 渦度の平均值分布}

各時刻の流速分布よりMLSによって求めた各時刻の 渦度分布を用いて渦度の平均值分布を求めた. また, 渦 度の変動強度を平均渦度から差の二乗平均平方根值と定 義して求めた. 図一7には水平断面の平均渦度および渦度 変動強度の分布を示し，図-8には鉛直断面の平均渦度お よび渦度変動強度分布を示寸.

まず，図-7 (a) に水平断面の平均渦度分布を示してい る.ピア曲率がないcase1およびピア曲率があるcase2の 場合は, 共通して時計回り (青色), 反時計回り (橙色)の 渦対が生じており, case1に比べてcase2の渦度が小さく なっていることがわかる，ピーク位置はcase 1 が $x=20 〜$ 25cmであるのに対して, case2が $x=10 〜 15 \mathrm{~cm}$ と終端壁側 に移動している．渦防止桁が設置されているcase3では 時計回り, 反時計回りの渦対が消失している.

図-7 (b) に渦度の変動強度の水平断面分布を示してい る. ピア曲率がないcase1の場合, 左岸側に渦度の変動 強度の大きい領域が存在する. 本実験では左岸側に旋回 流が卓越し, 旋回流自体の変動が大きいためと考えられ る. ピア曲率により, 渦度の変動強度のピーク值は低下 し, その領域が終端壁方向に移動している. 渦防止桁を 設置したcase3の終端壁付近の渦度変動強度の大きな領 域が消失している.

次に，図-8(a)に鉛直断面の平均渦度分布を示してい る. case1およびcase2では水面付近の時計回り(橙色)の 渦層が終端壁に向かって伸びているのがわかる. それに 対して, 洞防止桁が設置されているcase3では, その渦 層が斜め下方に向かって潜り込んでいる. また, ベルマ ウス接合部から剥離域に沿った反時計回り(青色)の渦層 がすべてのケースに存在する．渦防止桁を設置した case3の場合に最も長く伸びているのがわかる。これは 渦防止析により流れが整流され, 剥離域が安定したため と考えられる.

最後に, 図-8 (b) に渦度の変動強度の鉛直断面分布を 示している. case1およびcase2では終端壁水面近傍に ピークがみられるが，渦防止桁が設置されているcase3 ではそのピークが消失している. 主流部の渦度変動強度 はcase1より case2の方が低く抑えられ，ピア曲率により 渦が安定することがわかる. さらに, 渦防止桁を設置し たcase3の場合, 主流部の渦度変動強度がさらに低く抑 えられている. 渦防止桁により渦構造が安定することが 
(case1)
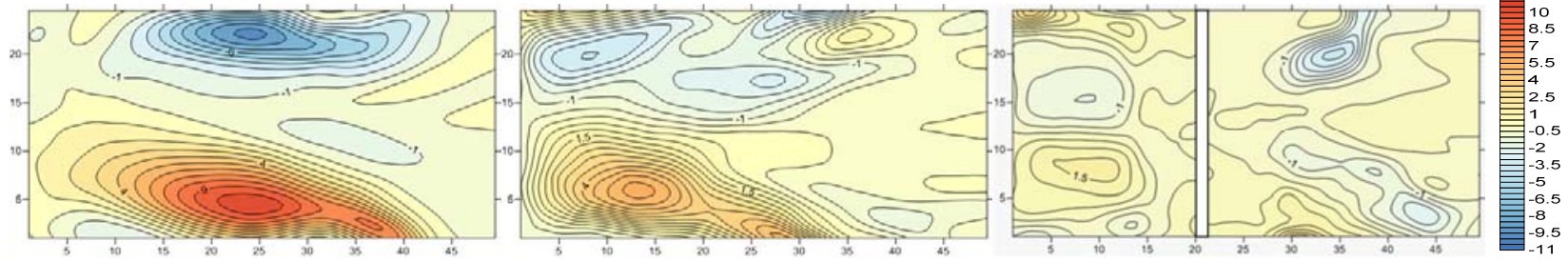

(a) 平均渦度分布

$(1 / \mathrm{sec})$
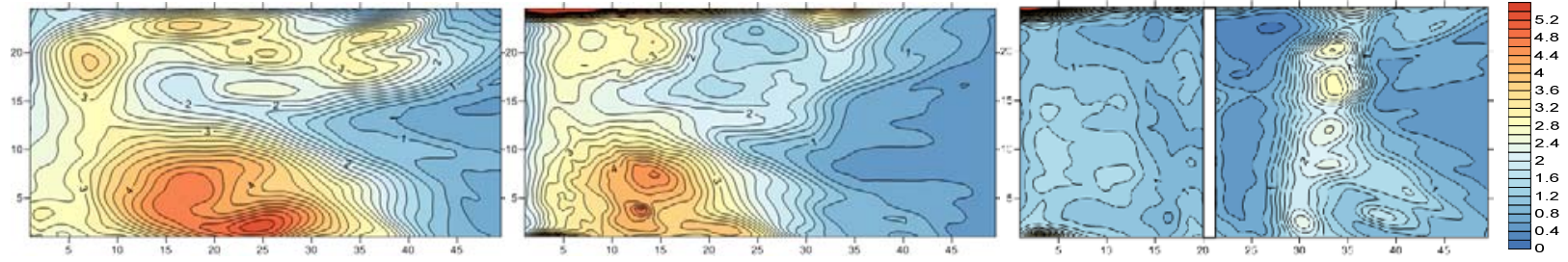

(b) 渦度の変動強度分布

図-7 水平断面 $(\mathrm{z}=0.04 \mathrm{~m})$ の平均渦度分布および渦度の変動強度分布 (横軸 $x$ 軸，縦軸 $y$ 軸，単位 $\mathrm{cm})$

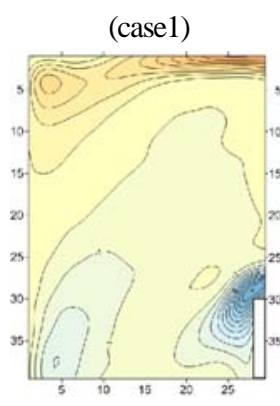

(case2) (case3)

$(1 / \mathrm{sec})$

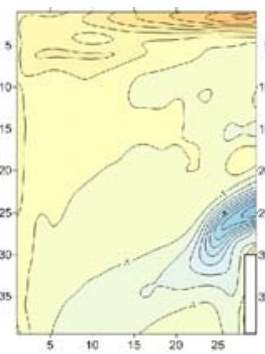

(a) 平均渦度分布
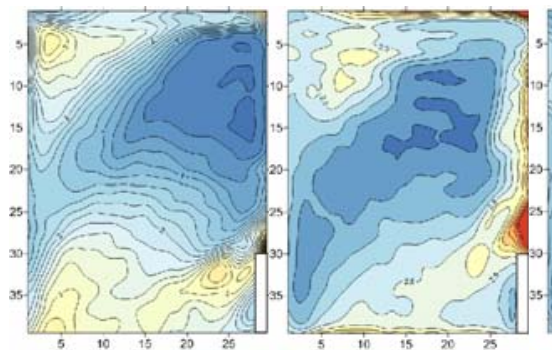

(b) 渦度の変動強度分布

図-8 鉛直断面 $(y=0.128 \mathrm{~m})$ の平均渦度分布および 渦度の変動強度分布(横軸x軸，縦軸軸，単位 $\mathrm{cm}$ )

わかる。

\section{5. まとめ}

水力発電施設で一般的に用いられる表面取水設備の模 型を用いて，空気取り込み渦に対する渦対策工の水理学 的影響を実験的に求めた. 実験ではPTV法により流れ場 の時系列の瞬時流速ベクトル分布を求め, 乱流統計量お よび渦度の統計量を評価した．今回の実験により以下の ようなことがわかった。

(1) ピア曲率がある場合とない場合の比較より，平均的 に生じる終端壁付近の時計回り，反時計回りの渦対 の位置がピア曲率の存在により下流側に移動する.
また乱流強度も低くなる。

(2) ピア曲率がない場合にはベルマウス接合部から終端 壁に乱流強度の大きな領域があるが，ピア曲率によ り低く抑えられている.

(3) 渦防止桁が存在する場合は水面近傍の終端壁に生じ る渦対がほぼ消滅する.

(4) 渦防止桁により，水面から取水管に向から流れが整 流され，乱れおよび渦度変動が抑制されている.

今後, 得られた渦度分布の時系列データをもとに, 詳 細な渦度の時空間的構造と空気取り込み渦の関係や空気 取り込み渦の発生条件を解明していく予定である.

\section{参考文献}

1) 荻原能男: 空気吸込み渦に関寸る研究, 土木学会論文報告集, 第215号，pp. 15-25， 1973.

2) ターボ機械協会 : ハイドロタービン（新改訂版），pp. 7581, 2007.

3) 栗津清蔵 : 流出渦について, 土木学会論文集, 第13号, pp. 46-54, 1952.

4) Hecker, G. E. : Fundamentals of vortex intake flow, in Swirling flow problems at intakes, edited by J.Knauss, pp. 13-38, A.A.Balkema, Rotterdam., 1987.

5) 和田章弘, 山本順平, 水島次郎 : 立軸ポンプ吸込口の形状と ポンプ性能，ターボ機械，第32巻，第10号，pp. 40-45, 2004.

6) 久未信幸, 中山昭彦 : LES法を用いた取水路内流れの数值シ ミュレーション，土木学会論文集B，Vol.64，No.4，pp. 251266, 2008.

7) 竹原幸生, Adrian, R. J., 江藤剛治 : KC法を用いた新しい Super-Resolution PIVの提案, 水工学論文集, 第44巻, pp. 431-436, 2000

8) 竹原幸生, 江藤剛治 : MLSを導入したPTVによる渦度推定法 の提案と風波流速場への適用，土木学会論文集B，Vol.65， No.3, pp. 151-165, 2009.

9) 久未信幸, 竹原幸生 : 画像計測を用いた取水渦の発生要因に 関する実験的検討，水工学論文集，第50巻，pp. 883-888, 2006.

(2013. 9. 30受付) 